\title{
Correction to: Opposition Based Joint Grey Wolf-Whale Optimization Algorithm Based Attribute Based Encryption in Secure Wireless Communication
}

\author{
M. Raja ${ }^{1} \cdot$ S. Dhanasekaran ${ }^{1} \cdot$ V. Vasudevan ${ }^{1}$
}

Published online: 2 April 2021

๑) Springer Science+Business Media, LLC, part of Springer Nature 2021

\section{Correction to: Wireless Personal Communications https://doi.org/10.1007/s11277-021-08357-8}

There was an error in the authors' affiliation in the initial online publication. The original article has been corrected.

Publisher's Note Springer Nature remains neutral with regard to jurisdictional claims in published maps and institutional affiliations.

The original article can be found online at https://doi.org/10.1007/s11277-021-08357-8.

M. Raja

kingraaja@gmail.com

S. Dhanasekaran

srividhans@gmail.com

V. Vasudevan

vasudevan_klu@yahoo.co.on

1 Department of Computer Science and Engineering, Kalasalingam Academy of Research and Education, Krishnankoil, Tamil Nadu, India 